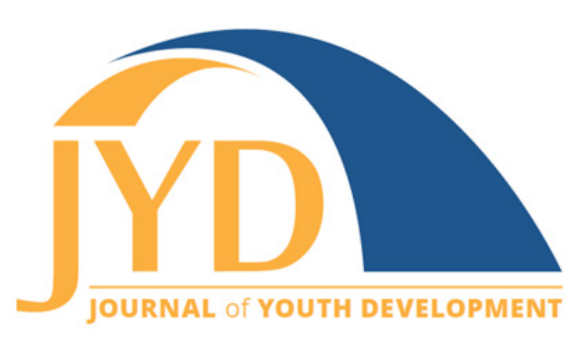

http://jyd.pitt.edu/ | Vol. 12 Issue 4 DOI 10.5195/jyd.2017.513 | ISSN 2325-4017 (online)

\title{
Adelante Ambassadors: Using Digital Media to Facilitate Community Engagement and Risk-Prevention for Latino Youth
}

\author{
Nicole Barrett \\ The George Washington University Milken Institute School of Public Health \\ ndbarrett@gwu.edu \\ Ricardo Villalba \\ Maryland Multicultural Youth Centers \\ ricardov@layc-dc.org

\section{Elizabeth Andrade} \\ The George Washington University Milken Institute School of Public Health \\ elandrade@gwu.edu
}

\section{Allison Beltran}

The George Washington University Milken Institute School of Public Health abeltran1@gwmail.gwu.edu

\section{W. Douglas Evans}

The George Washington University Milken Institute School of Public Health wdevans@gwu.edu

\begin{abstract}
Digital and social media are now widely used to promote engagement in health programs and improve health behaviors across a variety of age groups and domains. However, limited research exists on applying culturally relevant, new media interventions specific to Latino immigrant youth. This paper describes the pilot Adelante Youth Ambassador program for Latino immigrant youth, which used digital media and community-based participatory research to build positive youth development (PYD) assets as a prevention mechanism to reduce co-occurring health risks of substance use, sexual risk, and interpersonal violence. We worked collaboratively with adolescents to create video content as a conduit for Adelante-branded messages to be disseminated on the program's social media platforms. Using an active audience engagement methodology, youth participants informed the development of prevention messages, scripts for the videos, and acted in videos. Participants disseminated content to their social media networks and engaged peers in dialogue about topics addressed in the videos. Using pre and post tests, we evaluated changes in PYD assets (Civic Action Competence, Confidence, Connection to Community, and Connection to Peers) and skills related to digital media use, communication, and
\end{abstract}

(cc) EY New articles in this journal are licensed under a Creative Commons Attribution 4.0 License. This journal is published by the University Library System, University of Pittsburgh and is cosponsored by the University of Pittsburgh Press. The Journal of Youth Development is the official peer-reviewed publication of the National Association of Extension 4-H Agents and the National AfterSchool Association. 


\section{Adelante Ambassadors}

advocacy. The program used innovative branding and social media strategies to engage Latino youth in health risk prevention.

Key words: youth, adolescents, positive youth development, Latinos, immigrants, Hispanics, usergenerated content, social media, prevention

\section{Introduction}

Latinos accounted for more than half (54\%) of the total U.S. population growth from 2000 to 2014 and Latino adolescents represent $22.8 \%$ of the population ages 10-19 (Colby \& Ortman, 2015; Pew Research Center, 2016;). Yet, Latino adolescents face many health disparities, especially related to obesity, substance abuse, sexually transmitted infections, unintended pregnancy, and asthma (Eaton et al., 2012; Johnston, O’Malley, Bachman, \& Schulenberg, 2012; Moorman et al., 2012; Ogden, Carroll, Curtin, Lamb, \& Flegal, 2010; Ogden, Carroll, Kit, \& Flegal, 2014; Trejos-Castillo \& Vazsonyi, 2009). Latino adolescent immigrants (foreignborn)-in contrast to a significant proportion of the broader U.S. Latino population that has long, multigenerational roots in the country-face additional challenges of acculturation (Gamst et al., 2002; Smokowski \& Bacallao, 2007), familial separation and reunification patterns, documentation status (Cavazos-Rehg, Zayas, \& Spitznagel, 2007), and vulnerabilities at multiple levels (individual, peer, family, school, community) (Edberg et al., 2016) that could be unique potential contributors to mental health problems, coping strategies and risk-taking, and harmful behaviors and health outcomes (Potochnick \& Perreira, 2010). This group of youth therefore represents an important community that deserves public health intervention attention.

Digital and social media are now widely used to promote engagement in health programs and improve health behaviors across a variety of age groups and domains. (Centers for Disease Control and Prevention, 2011; Laranjo et al., 2015; Neiger et al., 2012). Innovative mobile and digital media strategies may influence health behavior, due to the ability to tailor content to specific audiences and connect with youth in an interactive and social way (Backinger, Fagan, Matthews, \& Grana, 2003; Montgomery \& Chester, 2009; Neiger et al., 2012). However, limited research exists on applying culturally relevant, new media interventions specific to Latino immigrant youth (Andrade et al., 2016; Bull, Levine, Black, Schmiege, \& Santelli, 2012; Friedman et al., 2014a; Friedman et al., 2014b; Martínez et al., 2014; Vyas, Landry, Schnider, Rojas, \& Wood, 2012; Young, Szekeres, \& Coates, 2013). This paper describes the pilot Youth Ambassador component of the Adelante program for Latino immigrant youth, which used digital media and community-based participatory research to build positive youth development (PYD) 


\section{Adelante Ambassadors}

assets as a prevention mechanism to reduce co-occurring health risks of substance use, sexual risk, and interpersonal violence.

\section{Background}

\section{Langley Park, Maryland}

Washington, DC now ranks with Los Angeles and New York as one of the largest Latino communities in the country (Migration Policy Institute, 2016; Pew Research Center, 2016). Langley Park, Maryland, located outside of Washington, DC, has become a major destination for recently arrived immigrant youth (Migration Policy Institute, 2016). In Langley Park, 76.6\% of residents self-identify as Hispanic or Latino and $67.8 \%$ are foreign born, primarily from Central American countries (Edberg \& Cleary, 2016; U.S. Census, 2010). Only 15\% of residents report being English proficient (The Urban Institute, 2014). It is a low-income community, with $90 \%$ of students receiving free or reduced-price lunches. Residents have limited educational attainment: two-thirds of adults lack a high school diploma, 57\% of adults have below a ninthgrade education, and 37\% of youth ages 16-19 are working and not in school (The Urban Institute, 2014).

The co-occurrence of substance abuse, risky sexual behavior, and violence among youth in Langley Park has been documented, and described elsewhere (Edberg \& Cleary, 2016; Edberg et al., 2016; Edberg et al., 2010; Edberg, Collins, Harris, McLendon, \& Santucci, 2009). The Avance Center for the Advancement of Immigrant/Refugee Health was established to address the health disparities among immigrant Latino youth in the community. This academiccommunity collaboration employs a multi-level intervention, called Adelante, which is a community-based youth program based on an adapted socio-ecological interpretation of PYD theory that builds youth, family, and community supports to address multiple contributing factors for co-occurring health issues (Edberg et al., 2016). PYD approaches emphasize assets (protective factors) as the key to prevention of negative behavior. According to Edberg et al. (2016) "the more assets youth possess, and the more assets they can access in their social environments, the less likely they are to engage in risk behavior, even when exposed to risk" (p. 490). Adelante PYD construct definitions were adapted from the "Five C's" of youth development (Lerner, 2005; Lerner \& Lerner, 2011; Silbereisen \& Lerner, 2007) to fit the unique socioeconomic and cultural context of the marginalized, minority youth in Langley Park (Edberg et al., 2016). Adelante's adapted PYD constructs represent the individual-level components of thriving despite adversity, including Competence, Confidence, and Connection, 


\section{Adelante Ambassadors}

as well as environmental components to create social capital, build capacity, and leverage community resources to establish linkages to a supportive environment important to immigrant youth circumstances. The overall Adelante program was designed to encompass a number of components, or activities, aimed at building youth assets and improving the social environment. Some of these components included one-on-one case management, prevention workshops, academic support, sports and recreation, and leadership and job readiness skill-building, among others, all to enhance these protective factors with the goal of building youth capacity for resiliency to avoid negative behaviors of substance abuse, risky sexual behavior, and interpersonal violence. An important part of Adelante was the program's engagement strategy, which included development of an Adelante brand identity, social media outreach, and other innovative engagement strategies, including the use of webnovelas to promote healthier choices and lifestyles (Andrade, Evans, Edberg, Cleary, \& Villalba, 2015). The Adelante Ambassadors program was one such Adelante youth activity, which served as a bridge between in-person PYD programming and Adelante engagement efforts.

\section{Digital Media for Adolescent Engagement}

Social media's ubiquitous use among Latinos (Lopez, Gonzalez-Barrera, \& Patten, 2013) provides an opportunity for traditionally unengaged or disadvantaged individuals to voice opinions. Cultural reasons can deter Latino youth from participating in community processes (Calzada, Fernandez, \& Cortes, 2010; Cubilla-Batista et al., 2016). However, social media advocacy offers opportunities for Latino youth to engage in community, national, or global dialogue about important issues that affect them, and at the same time, build advocacy skills by using an accessible platform that is familiar to them. Social media's instantaneous access allows for interventions driven by audience-generated content to increase youth ownership of prevention activities and messages and boost engagement among their social networks (Bottorff et al., 2014; Evans et al., 2016; Lenzi et al., 2015). Social media may also influence adolescent health behavior by enabling individuals to observe and model behaviors, attitudes, and outcomes (Bandura, 1977, 1986, 1998; Yi-Frazier et al., 2015). Evidence suggests Langley Park teens are avid mobile and social media users, with $84 \%$ reporting use of a smartphone for their primary internet access and $60 \%$ reporting use of the social networking platform Instagram (Andrade et al., 2016). However, research in other communities suggests digital media use and preferences among Latino teens can differ depending on nativity and language (Livingston \& Lopez, 2010; Smaldone et al., 2015; Vyas et al., 2012). To explore this further, and take advantage of the broad reach of social media in Langley Park, Adelante Ambassadors 


\section{Adelante Ambassadors}

acted as peer models in person, online, and in videos, providing concrete examples of resilient youth for their community peers to see (Bandura, 1986; Edberg et al., 2016).

\section{Adelante Ambassadors Program}

Adelante Ambassadors was a youth program within the larger intervention that aimed to build PYD assets in the target community. It was built upon the successes of Adelante's Victor \& Erika webnovela series (Andrade et al., 2015; Evans et al., 2016) and a pilot Social Media for Advocacy youth program. These activities contributed to the Adelante brand identity, which was developed in collaboration with youth, thus increasing brand engagement (Evans et al., 2016). Adelante's Victor \& Erika webnovela series was a pilot for brand execution. Youth created webbased dramatic episodes that told the stories of youth's struggles and successes in Langley Park (Andrade et al., 2015). Adelante Ambassadors aimed to build upon the webnovela series, but with shorter videos, by introducing different characters and storylines. The Social Media for Advocacy youth program tested a curriculum that used social media as a mechanism for youth civic engagement and to build PYD assets. We were beginning to engage community youth on social media and deemed this channel as promising for reaching this population. Youth leaders were trained to reach out via social media to advocate for a social or health issue of their choosing. With Adelante Ambassadors, we wanted to expand upon this program to include online youth engagement with Adelante-specific prevention messages and themes.

The Adelante Ambassadors program coincided with a year-long social marketing campaign that utilized digital and social media promotion, outdoor advertising, videos, and text messaging to augment Adelante program impact to the larger Langley Park youth community through changes in attitudes, norms, and risk behaviors (Andrade et al., 2016; Evans \& Hastings, 2008; Evans, Holtz, White, \& Snider, 2014; Kotler, P. \& Lee, N.R., 2008; ). Both the campaign and the Adelante Ambassador Program curriculum were guided by the overarching Adelante brand of turning the corner to a better life and four themes: (a) Adelante is... (meaning of Adelante), (b) making good choices, (c) living your dream, and (d) belonging to something bigger than yourself. Formative research informed the four campaign themes, which provided the message framework for videos and social media content in this program. Adelante Ambassadors was a small-scale, pilot program that was tested as a potential future channel for large-scale community reach. It was a pilot and not directly part of the community-wide campaign. 


\section{Adelante Ambassadors}

The Adelante Ambassadors program had five aims:

1. Integrate social marketing campaign themes into youth programming, as both happened simultaneously.

2. Produce youth-informed campaign messages, concepts, and content, and create products (videos) that bring the campaign messages to "life."

3. Build participants' PYD assets.

4. Increase youth leadership and advocacy skills to continue the Adelante dialogue online and with their peers.

5. Provide youth with valuable skills in digital media, advocacy, storytelling, and community engagement.

We assess the Adelante Ambassadors program's feasibility and acceptability as a tool to reach youth participants, improve PYD assets of Competence, Confidence, and Connection (Contribution was not part of this component of the overall Adelante program), and engage other youth in the community through social media. We also examine youth's overall level of interest in the program activities and present the content and themes of the messages and products that youth created.

\section{Methods}

\section{Setting and Participants}

Adelante Ambassador program activities took place in Langley Park, Maryland, a low-income, Latino immigrant community outside of Washington, DC. An equal female-to-male ratio of participants was recruited from the larger Adelante youth intervention cohort based on level of interest in acting and social media. The Adelante Ambassador program held 212 -hour sessions over seven months with 12 participants aged 14-18 years old. Due to the long duration, there was variation in the number of participants that would attend each week, and there was some attrition (see results). Sessions were conducted predominantly in English, but were also bilingual in Spanish, depending on participant preference. Sessions were led by a bilingual Adelante staff member with film experience and Avance Center research staff.

\section{Program Components}

The program was designed with a semi-structured curriculum that would meet our objectives and address desired health topics, but also offer enough flexibility for participants to be 


\section{Adelante Ambassadors}

engaged, lead the discussions, and have fun. The social marketing campaign themes (mentioned previously) guided the session topics (i.e. approximately five sessions focused on each of the four themes in secession with when each theme was rolled out). During each session, participants would engage in an interactive discussion about a campaign theme or health topic, learn and practice skills in social media, advocacy, and acting/improvisation, or create a program product (message, video, social media post, contest), described in detail below. Participants ("Ambassadors") represented the Adelante brand identity to the community through involvement in videos, social media, and community events.

\section{Messaging}

Ambassadors helped to refine social marketing campaign messages to ensure the continued integration of youth's perspectives. Messages were guided by the four campaign themes identified during formative research (Andrade et al., 2016; Evans et al., 2016). We revisited Adelante brand components including the logo, website, social media platforms, and Victor \& Erika webnovela series. We then introduced the media campaign's four themes, shared promotional materials, and brainstormed messages that could be used to further promote the themes to their peers.

\section{Videos}

Using active audience engagement (Hecht \& Miller-Day, 2010), participants informed messages, contributed to writing scripts, and acted in videos. Videos were both educational and entertaining. Videos addressed PYD-related topics and health behavioral outcomes of substance abuse, sexual risk and violence.

Script development was an iterative process between the researchers and participants. Ambassadors provided examples from their own lives that exemplified each campaign theme. Research staff prepared several video scenarios for participants to react to, which youth refined to include characters, location, and dialogue. Participants created dialogue with appropriate slang, language, and tone that they would use in their everyday lives.

Ambassadors also watched YouTube videos, short films, web series, and documentaries for inspiration. They participated in several improvisation and creativity exercises to build confidence in front of a group and practice acting skills. 


\section{Adelante Ambassadors}

\section{Social Media}

Ambassadors created social media content to post on Adelante social media platforms (Twitter, Facebook, and Instagram) to drive youth to the Adelante YouTube channel to see videos. The aim was for participants to also disseminate content to their own social media networks and engage peers in a dialogue about topics addressed in the videos.

Ambassadors learned ways to use social media to advocate for an issue and techniques to engage your audience. Youth use social media in their daily lives but may not leverage the power of social media beyond socializing with friends. The purpose was to provide them a foundation of why social media is important and prepare them to use it during the program for purposes of reaching their peer networks with targeted messages. We adapted the Social Media for Advocacy curriculum that had been previously tested. Ambassadors already knew the basics of how to use different platforms. We taught them strategies to enhance their skill set via techniques for engaging others online (tagging, hashtags, trending topics, use of images/videos, asking a poll or question). We reviewed social media accounts of organizations, brands, and influencers to examine the variety of techniques used to reach audiences and produce "viral" content. Youth then completed activities to practice these skills by crafting their own messages and informing posts for Adelante. Social media messages created during the program were disseminated through Adelante social media platforms and tracked.

\section{Contests}

Ambassadors participated in social media contests to "spread the word" and win prizes for boosting engagement. Participants created social media hashtags for each campaign theme, which were required to post for contest entry. Hashtags allowed researchers to identify winners and locate all content related to the contests. Contest duration ranged from 1 to 3 weeks on Facebook, Twitter, and Instagram and winners received $\$ 25$ and $\$ 50$ gift cards. Youth outside the Ambassador program were eligible to win.

\section{Community Events}

Ambassadors attended community events as Adelante brand representatives. The aim was for participants to embody the Adelante brand, act as leaders, share the Adelante messages to other youth, and connect with the community. 


\section{Data Collection and Measures}

Pre- and post-program surveys were collected to evaluate changes in the following PYD assets (Table 1): Confidence, Civic Action Competence, Community Connection, and Friend/Peer Connection. PYD construct measures were informed by or adapted from the referenced studies and reliability measures reported in Table 1 are from Adelante's 2014 community youth survey ( $n=724$ ) (Edberg et al., 2014). Surveys were collected during the first and last sessions of the program to gauge change over the 7 - month period.

Digital media and advocacy knowledge and perceived competence were also measured at post survey. Surveys and session attendance collected information about program participation. Process evaluation forms were collected and notes were taken for each session. Session notes and youth's message and video content ideas were analyzed to understand what youth believed was relevant to share with peers, what sentiments were expressed regarding certain health prevention topics, and how youth interpreted the Adelante brand through their content creation. Facebook Insights, Twitter Analytics, and Hootsuite were used to track social media engagement. All instruments and protocol were approved by The George Washington University Institutional Review Board. 
Table 1. Changes in Confidence, Civic Action Competence, Community Connection, and Friend/Peer Connection

\begin{tabular}{|c|c|c|c|c|}
\hline $\begin{array}{l}\text { PYD } \\
\text { Construct }\end{array}$ & Definition & Alpha & Sample Items & Program Activity Examples \\
\hline $\begin{array}{l}\text { Confidence, } 5 \\
\text { items (Edberg } \\
\text { et al., 2014; } \\
\text { Rosenberg, } \\
\text { 1965) }\end{array}$ & $\begin{array}{l}\text { 1) Components that increase positive self-image, such } \\
\text { as a cultural activity celebrating Latinos in the U.S.; or } \\
\text { 2) components that increase confidence in taking a } \\
\text { specific action - role-play exercises that increase } \\
\text { youths' self-esteem or confidence that they can } \\
\text { communicate effectively to a potential employer, } \\
\text { negotiate condom use with a partner or express their } \\
\text { opinion on a topic. }\end{array}$ & 0.79 & $\begin{array}{l}\text { Response options: } \\
\text { Strongly Disagree, } \\
\text { Disagree, Neutral, Agree, } \\
\text { Strongly Agree } \\
\text { I feel that I am a person } \\
\text { of value. }\end{array}$ & $\begin{array}{l}\text { Improvisational exercise in which } \\
\text { participants act out a short } \\
\text { scene about saying no to drugs } \\
\text { without using words, only } \\
\text { movement and facial } \\
\text { expressions. }\end{array}$ \\
\hline $\begin{array}{l}\text { Civic Action } \\
\text { Competence, } 5 \\
\text { items (Edberg } \\
\text { et al., 2014) }\end{array}$ & $\begin{array}{l}\text { Components that increase knowledge or skills about } \\
\text { how to engage in civic action, including advocacy } \\
\text { skills, how to organize a petition, or public } \\
\text { communication skills. }\end{array}$ & 0.95 & $\begin{array}{l}\text { Response options: I } \\
\text { definitely cannot, I } \\
\text { probably cannot, Maybe I } \\
\text { can, I probably can, I } \\
\text { definitely can } \\
\text { Get other people to care } \\
\text { about the problem }\end{array}$ & $\begin{array}{l}\text { Discuss as a group the problems } \\
\text { youth face in their community. } \\
\text { Create social media messages } \\
\text { and contests to address the } \\
\text { problem, invite others to } \\
\text { participate in the solution, and } \\
\text { motivate others to be resilient } \\
\text { despite adversity. }\end{array}$ \\
\hline
\end{tabular}


Table 1. (Cont.)

\begin{tabular}{|c|c|c|c|c|}
\hline $\begin{array}{l}\text { PYD } \\
\text { Construct }\end{array}$ & Definition & Alpha & Sample Items & Program Activity Examples \\
\hline $\begin{array}{l}\text { Community } \\
\text { Connection, } 4 \\
\text { items (Edberg } \\
\text { et al., 2014; } \\
\text { Flanagan, } \\
\text { Syversten, \& } \\
\text { Stout, 2007; } \\
\text { Karcher \& } \\
\text { Finn, 2005 ) }\end{array}$ & $\begin{array}{l}\text { 1) Components that promote a positive feeling about } \\
\text { or bonding to the community, increase the perceived } \\
\text { value of community engagement; or 2) activities that } \\
\text { create actual relationships to the community, such as } \\
\text { mentoring, connecting with community businesses, } \\
\text { and community journalism/blogging. }\end{array}$ & 0.94 & $\begin{array}{l}\text { Response options: } \\
\text { Strongly Disagree, } \\
\text { Disagree, Neutral, Agree, } \\
\text { Strongly Agree } \\
\text { I hang out a lot with other } \\
\text { youth in my neighborhood }\end{array}$ & $\begin{array}{l}\text { Create testimonial-style videos } \\
\text { that highlight Langley Park, MD } \\
\text { youth achievements and how } \\
\text { these individuals used local } \\
\text { resources and youth community } \\
\text { programs to help them succeed. }\end{array}$ \\
\hline $\begin{array}{l}\text { Friend/Peer } \\
\text { Connection, } 5 \\
\text { items (Edberg } \\
\text { et al., 2014; } \\
\text { Karcher \& } \\
\text { Finn, 2005) }\end{array}$ & $\begin{array}{l}\text { Components that promote the value of supportive } \\
\text { peers/friends, of involvement with peers/friends who } \\
\text { are heading in a positive direction; or } 2 \text { ) components } \\
\text { that actually provide activities or opportunities to } \\
\text { promote peer relationships, e.g., through group } \\
\text { activities, outings. }\end{array}$ & 0.92 & $\begin{array}{l}\text { Response options: } \\
\text { Strongly Disagree, } \\
\text { Disagree, Neutral, Agree, } \\
\text { Strongly Agree } \\
\text { I have friends I'm really } \\
\text { close to and trust } \\
\text { completely }\end{array}$ & $\begin{array}{l}\text { Collaboratively develop scripts } \\
\text { for each video by determining } \\
\text { storylines, characters, and } \\
\text { dialogue based on their own life } \\
\text { experiences. Film videos at } \\
\text { various off-site locations as a } \\
\text { group. }\end{array}$ \\
\hline
\end{tabular}




\section{Results}

The same 12 youth participated throughout the program, but weekly session attendance varied (3-12). On average, seven participants attended each week. They created the following media prducts and content.

\section{Videos}

Participants created four videos ranging between three and four minutes in length. Two of the videos shared two themes (Adelante Is and Making Good Choices, Table 2) and two shared the theme, Live Your Dream (Table 3). Videos were presented in English with Spanish subtitles, and either scripted or documentary/testimonial style. Youth recommended inclusion of topics relevant to their experiences and interests: sexual health, contraception, differential family immigration status and acculturation, support networks, overcoming obstacles, workforce preparation, and pursuing a higher education.

Table 2. Details for Adelante Ambassadors Videos with the Themes: Adelante Is and Making Good Choices

\begin{tabular}{|c|c|c|}
\hline & Video 1 & Video 2 \\
\hline Topic & Young women's perspective, sexual health & Young men's perspective, sexual health \\
\hline Location & Nail salon & Restaurant \\
\hline Type & Scripted & Scripted \\
\hline Details & $\begin{array}{l}\text { Knowledge about safe sex, discussing safe } \\
\text { sex with your romantic partner, not being } \\
\text { pressured to have sex, talking to trusted } \\
\text { adults for sexual health information, being } \\
\text { informed so as to be able make a good } \\
\text { decision for your health, support of friends } \\
\text { when making a hard decision }\end{array}$ & $\begin{array}{l}\text { Knowledge about safe sex, preventing } \\
\text { STDs, making the choice to use a condom, } \\
\text { discussing safe sex with your romantic } \\
\text { partner, preventing pregnancy, friendship }\end{array}$ \\
\hline
\end{tabular}


Table 3. Details for Adelante Ambassadors Videos with the Theme: Live Your Dream

\begin{tabular}{|c|c|c|}
\hline & Video 1 & Video 2 \\
\hline Topic & Dream professions for the future & $\begin{array}{l}\text { One Adelante participant shares her story, } \\
\text { the skills and experiences she gained from } \\
\text { the Adelante program, and her dreams for } \\
\text { the future }\end{array}$ \\
\hline Location & $\begin{array}{l}\text { Various workplace locations around } \\
\text { Maryland and Washington, DC }\end{array}$ & $\begin{array}{l}\text { Adelante office, Prince George's Community } \\
\text { College }\end{array}$ \\
\hline Type & Multiple youth testimonials & Individual youth testimonial \\
\hline Details & $\begin{array}{l}\text { Adelante Ambassadors talk about their plans } \\
\text { for the future and how they want to follow } \\
\text { their dreams, what professions they want to } \\
\text { work towards (actor, doctor, crime scene } \\
\text { investigator, nurse, computer programmer) }\end{array}$ & $\begin{array}{l}\text { Graduating high school, pursuing a college } \\
\text { education, overcoming obstacles, } \\
\text { persevering for your dreams, programs that } \\
\text { can help you succeed, planning for the } \\
\text { future, value of a support system, believing } \\
\text { in yourself }\end{array}$ \\
\hline
\end{tabular}

\section{Social Media Messages and Engagement}

\section{Messages}

The Adelante social marketing campaign generated 246 social media messages across all campaign themes. Ambassadors informed approximately half of the messages; other messages were informed by Adelante staff or created by research staff. Social media messages promoted campaign themes, Adelante Ambassador videos and contests, and were posted in both English and Spanish. Below are examples of youth-generated social media messages by theme.

Theme 1: Adelante is. Ambassadors suggested messages around building confidence, accessing opportunities, providing support, and helping to move their community forward. They also mentioned Adelante is knowledge, explaining that the Adelante programs on sexual health, career planning, and English tutoring provide important skills and information. 
There when you need it, helping you every step of the way. Adelante is support. It connects you with friends, family, or a trusted adult when you need help. Don't be afraid to ask for help when you need it.

Theme 2: Making good choices. Ambassadors suggested messages around talking to your friends, trusted adults, or Adelante staff to get support when making a difficult decision. Examples of difficult choices youth had to make included practicing safe sex, choosing a college or career path, and how to help a friend struggling with addiction or depression.

\section{Make decisions that don't put you at risk! Sexually transmitted infections, including HIV, are preventable. Take measures to protect yourself: always use a condom.}

Theme 3: Live your dream. Ambassadors suggested messages about setting goals and achieving them and working towards dreams both big and small. There was emphasis on little moments when you are living your dream, too. These included getting your driving permit, going to visit family in El Salvador for the first time, and auditioning and getting a part in a play. They also mentioned that living your dream is about pursuing an education and getting a job that pays well so you can support your family, after parents had sacrificed so much for their children. It was a dream to not live in fear of family members being deported for being undocumented. Barriers to achieving their dreams included the financial costs of higher education and unequal access to opportunities for U.S. minorities.

Is your dream to get a good job and help your family with the bills? Education is key, but you can also gain job skills for your future through internships and shadowing. Check out opportunities through Professional Pathways!

Theme 4: Belong to something bigger than yourself. Ambassadors looked to other social media advocacy activities to inform this theme. The goal was to motivate other youth about an issue. One example was \#BlackLivesMatter and police brutality. This brought up issues of racism and unequal access to services and opportunities for minorities. Youth suggested messages that unite people, bring the Latino community together, and voice opinions even if it means going against authority. 
If you don't speak up for your community's rights, who will? Our united voice can move us forward. Comment below and tell us about a problem you want addressed in your community!

\section{Tendencies \& Preferences}

Ambassadors had social media platform preferences. Participation with Adelante's Twitter account was lower compared to Adelante's Facebook and Instagram accounts. Many were interested in Snapchat, however the research team found challenges with this platform due to lack of tracking capabilities and lack of management sharing capabilities. In addition, prior to this program our community survey did not inquire about Snapchat use, so at the time we did not have data to justify including this platform in our activities.

One participant was not interested in social media and did not engage with Adelante on any social media. At least two participants did not have a cell phone, and using social media via a smartphone was not possible. Others were not comfortable posting original content to their own accounts; they would only participate with the Adelante social media platforms.

\section{Social Media Advocacy Knowledge \& Perceived Competence}

Survey results revealed strong social media advocacy knowledge and perceived competence to use social media for advocacy. The majority of participants (86\%) responded that they agreed or strongly agreed that "social media can be used to engage others in issues that are important to the community." A majority of participants (86\%) also agreed or strongly agreed that "advocacy is using your voice to share your opinion about an issue in your community that you would like to change." Most participants (71\%) agreed or strongly agreed that "I can use social media tools to teach others or share my ideas about an issue I want to change." This was measured at post-program survey only.

\section{Contests}

Three social media contests were conducted. The data reflect total engagement across Facebook, Twitter, and Instagram for each contest (Table 4). Youth were eligible for the contest by interacting in one of two ways: (a) via user-generated content or (b) engagement 
Adelante Ambassadors

Table 4. Adelante Ambassadors Social Media Contest Results

\begin{tabular}{|c|c|c|c|}
\hline Contest & \#AdelanteMovement & \#YourChoicesMatter & \#LiveYourDream \\
\hline Goal of Contest & $\begin{array}{l}\text { Join the Adelante Movement by } \\
\text { telling us what the Adelante } \\
\text { program and its message of } \\
\text { "moving forward" means to you. }\end{array}$ & $\begin{array}{l}\text { Tell us why your choices matter. Why } \\
\text { do you make certain choices and not } \\
\text { others? Who do you go to when you } \\
\text { have a difficult choice to make? }\end{array}$ & $\begin{array}{l}\text { Share what your dreams are for } \\
\text { the future, encourage youth to } \\
\text { pursue and achieve any dream } \\
\text { they have. }\end{array}$ \\
\hline $\begin{array}{l}\text { Ambassador Participation (how the } \\
\text { program participant gained entry } \\
\text { into the contest?) }\end{array}$ & 4 (user-generated); 3 (engagement) & 2 (user-generated); 2 (engagement) & 1 (user-generated) \\
\hline $\begin{array}{l}\text { Number of Contest Posts (combined } \\
\text { platforms) }\end{array}$ & 67 & 10 & 34 \\
\hline Likes (Instagram, Facebook) & 281 & 111 & 162 \\
\hline Comments (Instagram, Facebook) & 9 & 1 & 1 \\
\hline Shares (Facebook only) & 14 & 11 & 0 \\
\hline Retweets/Engagements (Twitter) & 31 & 0 & 21 \\
\hline Reach* (Facebook only) & 3,492 & 12,584 & 4,513 \\
\hline User-Generated Contest Entries & $6^{\mathrm{a}}$ & $2^{b}$ & $2^{c}$ \\
\hline
\end{tabular}

*Reach is the total number of people to whom the contest posts were served (unique users exposed to the content). ${ }^{\mathrm{a}}$ Themes included: Family, Opportunities, Learning, Personal and

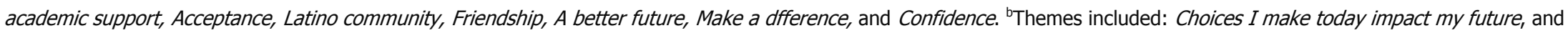
Choices I make reflect my value and integrity as a person. 'Themes included: Working with young people, Teaching/Education, Starting a charity, and Helping those in need. 


\section{Adelante Ambassadors}

with an existing Adelante social media post. User-generated content is defined as any type of unique content that has been created and posted by an individual or fan. It can refer to pictures, videos, testimonials, and tweets and is the act of users promoting a brand as opposed to the brand promoting itself. For example, an Ambassador responds to the contest entry specifications with his or her selfie and photo caption on his or her unique Facebook account page. An Ambassador could also enter the contest by engaging (react, like, share, comment) with an existing post on one of Adelante's social media platforms (not posting to their own account). Contest results show both Adelante Ambassador participation and engagement of the larger Adelante Langley Park youth community. Contest engagement varied. Contests that used paid Facebook boosts received more engagement because posts were more visible on newsfeeds. Contests that promoted Adelante Ambassador videos were more appealing than a static photo or status update.

\section{Community Events}

Adelante Ambassadors participated in two local events. Youth attended a National Council of La Raza event on Capitol Hill about Latino political participation. Youth met with congressional representatives, advocated for immigration reform, and learned about the importance of voting.

Youth also attended a Parents as Leaders workshop on bullying, a collaboration between local community organizations, public schools, parents and students to address bullying in schools. Parents were informed of the warning signs of being bullied and provided resources for working with the schools to address the problem. Ambassadors acted as youth representatives and assisted with filming the event.

\section{Changes in PYD Constructs}

As part of the larger Adelante PYD intervention, the Adelante Ambassadors program aimed to enhance assets of youth. Figure 1 depicts the percentages of participants experiencing positive, negative or no change in four PYD assets. Two-thirds of participants showed an increase in Civic Action Competence and over half showed an increase in Community Connection. There were slight improvements in Confidence with four out of nine participants improving and two showing no change. Less improvement was seen for Friend/Peer Connection, but still three out of nine participants improved. 
Adelante Ambassadors

Figure 1: Percent of Participants with Variation in Pre/Post PYD Asset

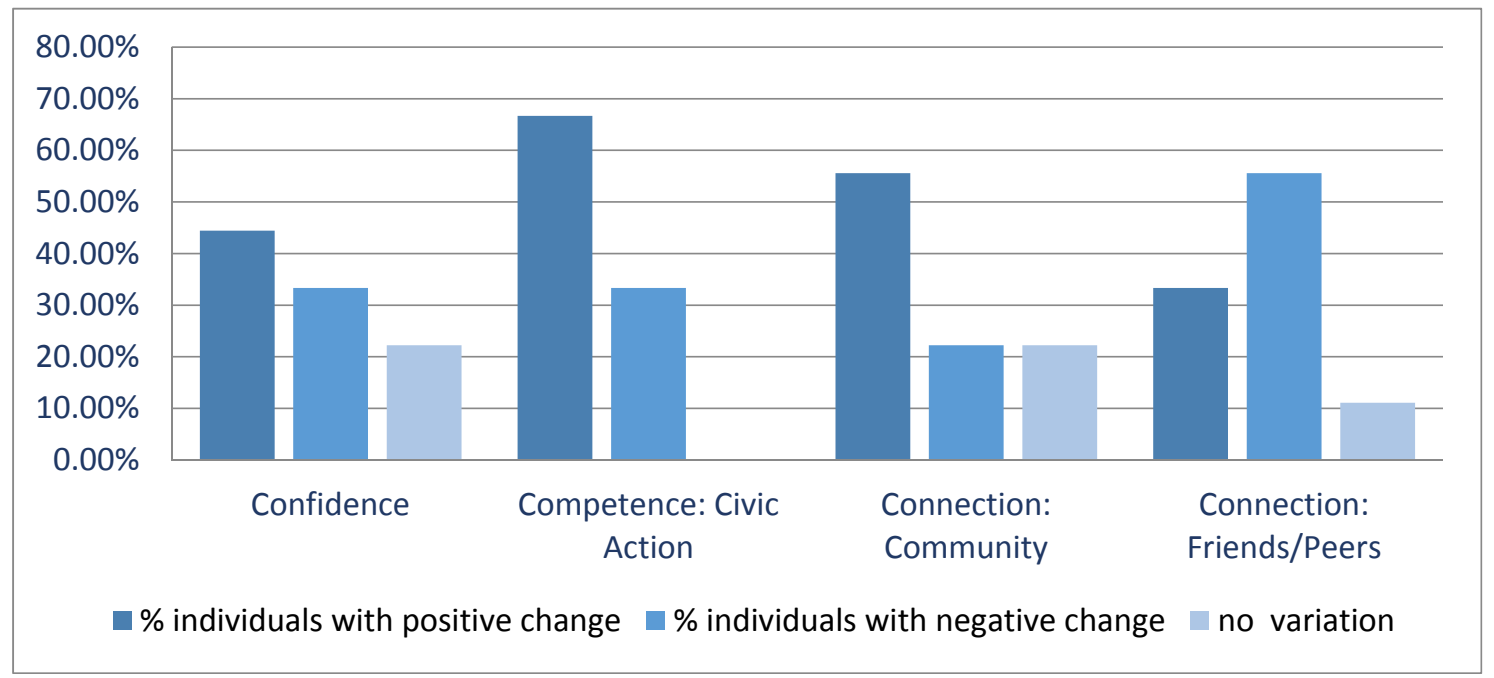

\section{Discussion}

The purpose of this study was to assess the program's feasibility to determine its appeal for use in promoting positive health behaviors in this population. We believe this approach to be promising for engaging Latino immigrant youth.

Youth were interested, willing, and active participants in the Adelante Ambassador program. As a result of their experiences as Adelante Ambassadors (in-person, online, and in videos), a group that is traditionally disengaged or excluded from civic participation and typically disconnected from their community showed improvement in these PYD assets. The program was successful in engaging youth in the process of message, video, and contest creation. Youth provided valuable insight into social media posts for each theme as the social marketing campaign unfolded. Creation of videos offered youth new skills and an outlet for sharing stories of their lives.

Some strategies for engaging youth were more effective than others. The semi-structured curriculum, youth-led/active audience engagement methodology led to a fun and engaging program, and videos and content that were educational, entertaining, and authentic. However, youth's social media platform preferences varied. It is important to include all social media platforms youth prefer in the program, so youth can use the platform with which they are most familiar and comfortable. Unfortunately, emerging media such as Snapchat was of interest to participants, but this platform poses tracking challenges for evaluation. 
Youth use of social media also varied. Some did not have access to mobile devices for instantaneous social media activity. For those that did have devices, we found that varying connectivity to internet/data plans impacted youths' ability to connect. Despite the popularity of social media and mobile technologies among Latinos nationally (Lopez et al., 2013) and among adolescents surveyed in Langley Park, Maryland (Andrade et al., 2016), the Langley Park population's media use trends may vary based on socioeconomic status, United States vs. foreign-born, and acculturation. A Pew Hispanic Center teen survey on mobile and social media use found that the use of mobile technology and social media sites greatly differs among Latino teens depending on nativity and language (Livingston \& Lopez, 2010). In a study of ninth- and tenth-grade, self-identifying Latino adolescents from public high schools in Maryland, recent immigrants (within the last three years) and Spanish-dominant respondents had significantly less access and less frequent use of social media (Vyas, Landry, Schnider, Rojas, \& Wood, 2012). Similarly, Smaldone et al. (2015) surveyed urban, underserved Latino adolescents about their mobile technologies and social media use and found that most youth lacked an interest in using social media for health communication despite the medium's widespread use among the population (Smaldone et al., 2015). Respondents who were foreign born were less likely to be interested in using social media for health communication than U.S. born Latinos (Smaldone et al., 2015). Our findings suggest that the content and format of social media health communication matters. Contests and videos boosted social media engagement, but usergenerated content was limited. In a study piloting Instagram as a modified application of PhotoVoice storytelling among adolescents with type I diabetes, similar engagement and retention barriers occurred (Yi-Frazier et al., 2015). Of 47 youth approached, 20 enrolled and only 12 youth actively posted user-generated content on Instagram. Reasons for not engaging included not interested in Instagram platform, not being interested in social media in general, not having the proper mobile phone, or being too busy (Yi-Frazier et al., 2015).

Participants were hesitant to post user-generated content to their social media accounts and preferred to use social media to engage with content on other accounts. Youth were more comfortable "liking" Adelante program posts rather than higher level activities such as commenting, sharing, and posting user-generated content. This finding aligns with the categorization of Internet users O'Neill et al. (2014) coin as "lurkers," those who do not actively contribute health content but who consume content (O'Neill, Ziebland, Valderas, \& LupiáñezVillanueva, 2014). Similarly, re-posting "internet memes" and generic photos not addressing a participant's personal life has been found to be preferred among this age group (Yi-Frazier et al., 2015). Fergie, Hunt, \& Hilton (2016) found similar hesitancy among adolescents and young 


\section{Adelante Ambassadors}

adults to use social media to post user-generated content related to diabetes and mental health because of daily online identity management. Youth described a complex decision-making process to ensure social media content fit with their online persona, which in turn acted as a barrier to health-related content production (Fergie et al., 2016).

\section{Conclusion}

The Adelante Ambassadors program used innovative branding and social media strategies to engage Latino youth in risk prevention and increase PYD assets. Using a multi-pronged approach including in-person activities, a youth-informed social marketing campaign, social media advocacy, and video edutainment, the program offers a novel way to engage Latino immigrant youth in health promotion activities that foster positive development.

The mixed success of social media in our study, along with the positive successes of interacting in program sessions and youth creation of authentic messages and videos, demonstrates the importance of in-person youth programs that are dynamic and offer youth multiple ways to participate, depending on their interest and accessibility. We recommend interpersonal communication be included in youth programming for this population in conjunction with new and innovative media efforts. In addition, our program offered cash prizes for contest winners, but did not offer financial incentives to youth participants for regularly engaging with program components or attending program sessions. A financial incentive may be needed to keep participation high over many months and should be explored further.

Efforts should be made to ensure youth recruited to future programs are interested in social media, able to access it, and are comfortable posting user-generated content to the medium. Social media privacy concerns should be discussed prior to enrollment in the program. Incentives for engagement should be further explored. This unique digital and new media program for youth has already been adapted in another setting for substance use prevention, further demonstrating the importance of doing an early descriptive pilot study for future innovations (Evans et al., 2017). 


\section{Acknowledgements}

This study was supported by grant number MD006898 from the National Institute for Minority Health and Health Disparities. We gratefully acknowledge the valuable contributions of our partners at the Maryland Multicultural Youth Centers.

\section{References}

Andrade, E. L., Evans, W. D., Barrett, N., Kierstead, L., Beltran, A., Villalba, R. O., Cleary, S. D. (2016). Development of the place-based Adelante social marketing campaign for prevention of substance use, sexual risk and violence among Latino immigrant youth. Unpublished manuscript.

Andrade, E. L., Evans, W. D., Edberg, M. C., Cleary, S. D., \& Villalba, R. (2015). Victor and Erika webisodes for the Adelante brand: An innovative audience engagement strategy for prevention. Journal of Health Communication, 20(12), 1465-1472. doi:10.1080/10810730.2015.1018648 http://www.tandfonline.com/doi/full/10.1080/10810730.2015.1018648

Backinger, C. L., Fagan, P., Matthews, E., \& Grana, R. (2003). Adolescent and young adult tobacco prevention and cessation: Current status and future directions. Tobacco Control, 12 (Supplement IV), iv46-iv53. http://tobaccocontrol.bmj.com/content/12/suppl_4/iv46.long

Bandura, A. (1977). Social learning theory. Englewood Cliffs, NJ: Prentice Hall.

Bandura, A. (1986). Social foundations of thought and action: A social cognitive theory. Englewood Cliffs, NJ: Prentice Hall.

Bandura, A. (1998). Health promotion from the perspective of social cognitive theory. Psychology \& Health, 13(4), 623-649. http://www.tandfonline.com/doi/abs/10.1080/08870449808407422

Bottorff, J. L., Struik, L. L., Bissell, L. J. L., Graham, R., Stevens, J., \& Richardson, C. G. (2014). A social media approach to inform youth about breast cancer and smoking: An exploratory descriptive study. Collegian, 21(2), 159-168. doi:10.1016/j.colegn.2014.04.002 http://www.sciencedirect.com/science/article/pii/S1322769614000377

Bull, S. S., Levine, D. K., Black, S. R., Schmiege, S. J., \& Santelli, J. (2012). Social media-delivered sexual health intervention: A cluster randomized controlled trial. American Journal of Preventive Medicine, 43(5), 467-474. doi: 10.1016/j.amepre.2012.07.022

Calzada, E. J., Fernandez, Y., \& Cortes, D. E. (2010). Incorporating the cultural value of respeto into a framework of Latino parenting. Cultural Diversity \& Ethnic Minority Psychology, 16(1), 77-86. https://www.ncbi.nlm.nih.gov/pmc/articles/PMC4403003/

Cavazos-Rehg, P.A., Zayas, L. H., \& Spitznagel, E. L. (2007). Legal status, emotional well-being and subjective health status of Latino immigrants. Journal of the National Medical Association, 99(10), 1126-1131. https://www.ncbi.nlm.nih.gov/pmc/articles/PMC2574408/ 


\section{Adelante Ambassadors}

Centers for Disease Control and Prevention. (2011). The health communicator's social media toolkit. Retrieved from http://www.cdc.gov/socialmedia/tools/guidelines/pdf/socialmediatoolkit_bm.pdf

Colby, S. L., \& Ortman, J. M. (2015, March). Projections of the size and composition of the U.S. population: 2014 to 2060. United States Census Bureau. Retrieved from https://census.gov/content/dam/Census/library/publications/2015/demo/p25-1143.pdf

Cubilla-Batista, I., Andrade, E. L., Cleary, S. D., Edberg, M., Evans, W. D., Simmons, L. K., \& Sojo-Lara, G. (2016). Picturing Adelante: Latino youth participate in CBPR using place-based PhotoVoice. Social Marketing Quarterly, 23(1), 18-35. doi: 10.1177/1524500416656586 http://journals.sagepub.com/doi/full/10.1177/1524500416656586

Eaton, D. K., Kann, L., Kinchen, S., Shanklin, S., Flint, K. H., Hawkins, J., . . Wechsler, H. (2012). Youth Risk Behavior Surveillance - United States, 2011. Centers for Disease Control and Prevention. Atlanta, GA.

Edberg, M. C., \& Cleary, S. D. (2016). Adelante Langley Park demographic data. Unpublished manuscript. Edberg, M. C., Cleary, S. D., Andrade, E. L., Evans, W. D., Simmons, L. K., \& Cubilla-Batista, I. (2016). Applying ecological positive youth development theory to address co-occurring health disparities among immigrant Latino youth. Health Promotion Practice, 1-9. https://doi.org/10.1177/1524839916638302

Edberg, M. C., Cleary, S. D., Collins, E. C., Klevens, J., Leiva, R., Bazurto, M., Calderon, M. (2010). The SAFER Latinos project: Addressing a community ecology underlying Latino youth violence. Journal of Primary Prevention, 31(4), 247-257. doi: 10.1007/s10935-010-0219-3

Edberg, M. C., Cleary, S. D., Evans, W. D., Andrade, E. L., Rivera, M. I., Barrett, N., . . Cubilla-Batista, I. (2014). [Adelante community youth survey data]. Unpublished raw data.

Edberg, M. C., Collins, E. C., Harris, M., Mclendon, H., \& Santucci, P. (2009). Patterns of HIV/AIDS, STI, substance abuse and hepatitis risk among selected samples of Latino and African-American youth in Washington, DC. Journal of Youth Studies, 12(6), 685-709. http://dx.doi.org/10.1080/13676260902897400

Evans, W., Andrade, E., Goldmeer, S., Smith, M., Snider, J., \& Girardo, G. (2017). The Living the Example social media substance use prevention program: A pilot evaluation. Journal of Medical Internet Research Mental Health, 4(2), e24. doi: 10.2196/mental.7839

Evans, W. D., Andrade, E., Villalba, R., Cubilla, I., Rivera, I., \& Edberg, M. (2016). Turning the corner: Development of the Adelante program brand for Latino youth. Social Marketing Quarterly, 22(1), 19-33. http://journals.sagepub.com/doi/full/10.1177/1524500415614838

Evans, W. D., \& Hastings, G. (Eds.) (2008). Public health branding: Applying marketing for social change. Oxford, UK: Oxford University Press. 


\section{Adelante Ambassadors}

Evans, W. D., Holtz, K., White, T., \& Snider, J. (2014). Effects of the above the influence brand on adolescent drug use prevention beliefs. Journal of Health Communication, 19(6), 721-37. doi:10.1080/10810730.2013.837559

Fergie, G., Hunt, K., \& Hilton, S. (2016). Social media as a space for support: Young adults' perspectives on producing and consuming user-generated content about diabetes and mental health. Social Science \& Medicine, 170, 46-54. doi:10.1016/j.socscimed.2016.10.006 https://www.ncbi.nlm.nih.gov/pubmed/27750067

Flanagan, C. A., Syversten, A. K., \& Stout, M. D. (2007). Civic measurement models: Tapping adolescents' civic engagement. College Park, MD: CIRCLE.

Friedman, A. L., Bozniak, A., Ford, J., Hill, A., Olson, K., Ledsky, R., Inokuchi, D., \& Brookmeyer, K. (2014a). Reaching youth with sexually transmitted disease testing: Building on successes, challenges, and lessons learned from local Get Yourself Tested campaigns. Social Marketing Quarterly, 29(2), 116-138. http://journals.sagepub.com/doi/abs/10.1177/1524500414530386

Friedman, A. L., Brookmeyer, K. A., Kachur, R. E., Ford, J., Hogben, M., Havel, M. A., Kantor, L. M., Clark, E., Sabatini, J., \& McFarlane, M. (2014b). An assessment of the GYT: Get Yourself Tested Campaign: An integrated approach to sexually transmitted disease prevention communication. Sexually Transmitted Diseases, 41(3), 151-157. doi: 10.1097/OLQ.0000000000000100

Gamst, G., Dana, R. H., Der-Karabetian, A., Aragon, M., Arellano, L. M., \& Kramer, T. (2002). Effects of Latino acculturation and ethnic identity of mental health outcomes. Hispanic Journal of Behavioral Sciences, 24(4), 479-504. https://doi.org/10.1177/0739986302238216

Hecht, M. L., \& Miller-Day, M. (2010). "Applied" aspects of the drug resistance strategies project. Journal of Applied Communication Research, 38(3), 215-229. doi:10.1080/00909882.2010.490848 http://www.tandfonline.com/doi/abs/10.1080/00909882.2010.490848

Johnston, L. D., O’Malley, P. M., Bachman, J. G., \& Schulenberg, J. E. (2012). Monitoring the future, national results on adolescent drug use: Overview of key findings, 2011. Ann Arbor: Institute for Social Research, the University of Michigan.

Karcher, M. J. \& Finn, L. (2005). How connectedness contributes to experimental smoking among rural youth: Developmental and ecological analyses. Journal of Primary Prevention, 26(1), 25-36. doi: 10.1007/s10935-004-0989-6

Kotler, P. \& Lee, N.R. (Ed.). (2008). Social marketing: Influencing behaviors for social good(3rd ed.). Thousand Oaks, CA: Sage Publications.

Laranjo, L., Arguel, A., Neves, A. L., Gallagher, A. M., Kaplan, R., Mortimer, N., . . Lau, A. Y. S. (2015). The influence of social networking sites on health behavior change: A systematic review and metaanalysis. Journal of the American Medical Informatics Association, 22(1), 243-256. doi:10.1136/amiajnl-2014-002841 https://academic.oup.com/jamia/articlelookup/doi/10.1136/amiajnl-2014-002841 
Adelante Ambassadors

Lenzi, M., Vieno, A., Altoè, G., Scacchi, L., Perkins, D. D., Zukauskiene, R., \& Santinello, M. (2015). Can Facebook informational use foster adolescent civic engagement? American Journal of Community Psychology, 55(3-4), 444-454. doi:10.1007/s10464-015-9723-1 http://onlinelibrary.wiley.com/doi/10.1007/s10464-015-9723-1/full

Lerner, R. M. (2005, September). Promoting positive youth development: Theoretical and empirical bases. White Paper Prepared for a Workshop on the Science of Adolescent Health and Development, National Research Council, Washington, DC.

Lerner, R. M., \& Lerner, J. V. (2011). The positive development of youth: Report of the findings from the first seven years of the 4-H study on positive youth development. Medford, MA: Tufts University Institute for Applied Research in Positive Youth Development and the National 4-H Council.

Livingston, G. \& Lopez, M. H. (2010, July 28). How young Latinos communicate with friends in the digital age. Washington, DC: Pew Hispanic Center. http://www.pewhispanic.org/2010/07/28/how-younglatinos-communicate-with-friends-in-the-digital-age/

Lopez, M. H., Gonzalez-Barrera, A. \& Patten, E. (2013). Closing the digital divide: Latinos and technology adoption. Retrieved from http://www.pewhispanic.org/files/2013/03/Latinos_Social_Media_and_Mobile_Tech_032013_final.pdf

Martínez, O., Wu, E., Shultz, A. Z., Capote, J., Lopez Rios, J., Sandfort, T., . . Rhodes, S. D. (2014). Still a hard-to-reach population? Using social media to recruit Latino gay couples for an HIV intervention adaptation study. Journal of Medical Internet Research, 16(4), 1-14. doi: 10.2196/jmir.3311

Migration Policy Institute. (2016). The immigration population in the Washington, D.C. region and the service needs of Central American child and family migrants. Regional Conference on Advancing Health Equity for Latino Youth \& Families, Washington, DC.

Montgomery, K. C. \& Chester, J. (2009). Interactive food and beverage marketing: Targeting adolescents in the digital age. Journal of Adolescent Health, 45(3), S18-S29.

doi: https://doi.org/10.1016/j.jadohealth.2009.04.006

Moorman, J. E., Akinbami, L. F., Bailey, C. M., Zahran, H. S., King, M. E., Johnson, C.A., \& Liu, X. (2012). National Surveillance of Asthma: United States, 2001-2010, table 2. Centers for Disease Control and Prevention. Atlanta, GA.

Neiger, B. L., Thackeray, R., Van Wagenen, S. A., Hanson, C. L., West, J. H., Barnes, M. D., \& Fagen, M. C. (2012). Use of social media in health promotion: Purposes, key performance indicators, and evaluation metrics. Health Promotion Practice, 13(2), 159-164. doi: 10.1177/1524839911433467 http://journals.sagepub.com/doi/10.1177/1524839911433467

Ogden, C. L., Carroll, M. D., Curtin, L. R., Lamb, M. M., \& Flegal, K. M. (2010). Prevalence of high body mass index in US children and adolescents, 2007-2008. Journal of the American Medical Association, 303(3), 242-249. doi:10.1001/jama.2009.2012 
Adelante Ambassadors

Ogden, C. L., Carroll, M. D., Kit, B. K., \& Flegal, K. M. (2014). Prevalence of childhood and adult obesity in the United States, 2011-2012. Journal of the American Medical Association, 311(8), 806-814. doi:10.1001/jama.2014.732

O'Neill, B., Ziebland, S., Valderas, J., \& Lupiáñez-Villanueva, F. (2014). User-generated online health content: A survey of internet users in the United Kingdom. Journal of Medical Internet Research, 16(4), 1-11. https://www.jmir.org/2014/4/e118/

Pew Research Center. (2016). U.S. Latino population growth and dispersion has slowed since onset of the great recession. Retrieved from http://www.pewresearch.org/fact-tank/2016/09/08/key-facts-abouthow-the-u-s-hispanic-population-is-changing/

Potochnick, S. R., \& Perreira, K. M. (2010). Depression and anxiety among first-generation immigrant Latino youth: Key correlates and implications for future research. The Journal of Nervous and Mental Disease, 198(7), 470-477. http://doi.org/10.1097/NMD.0b013e3181e4ce24

Rosenberg, M. (1965). Society and the adolescent self-image. Princeton, NJ: Princeton University Press. Silbereisen, R. K., \& Lerner, R. M. (2007). Approaches to positive youth development. London: Sage.

Smaldone, A., Stockwell, M. S., Osborne, J. C., Cortes, Y., Bekele, E., \& Green, N. S. (2015). Adolescent and parent use of new technologies for health communication: A study in an urban Latino community. Journal of Public Health Research, 4(1), 13-18. doi:10.4081/jphr.2015.376 http://www.jphres.org/index.php/jphres/article/view/376/228

Smokowski, P. R. \& Bacallao, M. L. (2007). Acculturation, internalizing mental health symptoms, and selfesteem: Cultural experiences of Latino adolescents in North Carolina. Child Psychiatry and Human Development, 37(3), 273-292. doi: 10.1007/s10578-006-0035-4

Trejos-Castillo, E. \& Vazsonyi, A. T. (2009). Risky sexual behaviors in first and second generation Hispanic immigrant youth. Journal of Youth and Adolescence, 38(5), 719-731. https://link.springer.com/article/10.1007/s10964-008-9369-5

The Urban Institute. (2014). From cradle to career: The multiple challenges facing immigrant families in Langley Park promise neighborhood. Retrieved from http://www.urban.org/sites/default/files/alfresco/publication-pdfs/413164-From-Cradle-to-CareerThe-Multiple-Challenges-Facing-Immigrant-Families-in-Langley-Park-Promise-Neighborhood.PDF

U.S. Census. (2010). QuickFacts Langley Park CDP, Maryland. Retrieved from http://www.census.gov/quickfacts/table/PST045215/2445525,00

Vyas, A. N., Landry, M., Schnider, M., Rojas, A. M., \& Wood, S. F. (2012). Public health interventions: Reaching Latino adolescents via short message service and social media. Journal of Medical Internet Research, 14(4), e990. doi:10.2196/jmir.2178

Yi-Frazier, J., Cochrane, K., Mitrovich, C., Pascual, M., Buscaino, E., Eaton, L., . . Malik, F. (2015). Using Instagram as a modified application of PhotoVoice for storytelling and sharing in adolescents with 
Journal of Youth Development | http://jyd.pitt.edu/ | Vol. 12 Issue 4 DOI 10.5195/jyd.2017.513

Adelante Ambassadors

type 1 diabetes. Qualitative Health Research, 25(10), 1372-1382. doi: 10.1177/1049732315583282 http://journals.sagepub.com/doi/abs/10.1177/1049732315583282

Young, S. D., Szekeres, G., \& Coates, T. (2013). Sexual risk and HIV prevention behaviours among African-American and Latino MSM social networking users. International Journal of STD \& AIDS, 24(8), 643-649. http://journals.sagepub.com/doi/10.1177/0956462413478875 